\title{
Cutaneous susceptibility to SARS-CoV-2 infection according to the expression of viral entry factors in the skin
}

\author{
Myriam Garduño-Soto ${ }^{1 *}$ and José A. Choreño-Parra²
}

'Secretaría de Salud, Hospital General de México "Dr. Eduardo Liceaga", Dermatology Department; ${ }^{2}$ Instituto Politécnico Nacional, National School of Biological Sciences. Mexico City, Mexico

\begin{abstract}
Introduction: Reports of dermatological manifestations in patients with COVID-19 suggest a possible cutaneous tropism of SARS-CoV-2; however, the capacity of this virus to infect the skin is unknown. Objective: To determine the susceptibility of the skin to SARS-CoV-2 infection based on the expression of viral entry factors ACE2 and TMPRSS2 in this organ. Method: A comprehensive analysis of human tissue gene expression databases was carried out looking for the presence of the ACE2 and TMPRSS2 genes in the skin. mRNA expression of these genes in skin-derived human cell lines was also assessed. Results: The analyses showed high co-expression of ACE2 and TMPRSS2 in the gastrointestinal tract and kidney, but not in the skin. Only the human immortalized keratinocyte HaCaT cell line expressed detectable levels of ACE2, and no cell line originating in the skin expressed TMPRSS2. Conclusions: Our results suggest that cutaneous manifestations in patients with COVID-19 cannot be directly attributed to the virus. It is possible that cutaneous blood vessels endothelial damage, as well as the effect of circulating inflammatory mediators produced in response to the virus, are the cause of skin involvement.
\end{abstract}

KEY WORDS: SARS-COV-2. COVID-19. Viral skin infections. COVID-19 cutaneous manifestations. ACE2.

\section{Susceptibilidad cutánea a la infección por SARS-CoV-2 según la expresión de los factores de entrada viral en la piel}

\section{Resumen}

Introducción: Reportes de manifestaciones dermatológicas en pacientes con COVID-19 sugieren un posible tropismo cutáneo del virus SARS-CoV-2; sin embargo, se desconoce la capacidad de este virus para infectar la piel. Objetivo: Determinar la susceptibilidad de la piel a la infección por SARS-CoV-2 con base en la expresión de los factores de entrada viral ACE2 y TMPRSS2 en dicho órgano. Método: Se buscaron los genes ACE2 y TMPRSS2 en la piel, para lo cual se realizó un análisis extenso de las bases de datos de expresión genética en tejidos humanos. Asimismo, se evaluó la expresión de dichos genes en líneas celulares humanas derivadas de la piel. Resultados: Los análisis mostraron alta expresión conjunta de ACE2 y TMPRSS2 en el tracto gastrointestinal y en los riñones, pero no en la piel. Solo la línea celular de queratinocitos humanos inmortalizados HaCaT expresó niveles detectables de ACE2 y ninguna línea celular de origen cutáneo expresó TMPRSS2. Conclusiones: Los resultados sugieren que las manifestaciones dermatológicas en pacientes con COVID-19 no pueden ser atribuidas directamente al virus; es posible que sean originadas por el daño endotelial a los vasos sanguíneos cutáneos y el efecto de los mediadores inflamatorios circulantes producidos en respuesta al virus.

PALABRAS CLAVE: SARS-CoV-2. COVID-19. Infecciones virales de la piel. Manifestaciones cutáneas de COVID-19. ACE2. 


\section{Introduction}

The appearance of the new coronavirus associated with severe acute respiratory syndrome 2 (SARSCoV-2) constitutes a public health emergency of international importance. By May 19, 2020, the human infection caused by this virus, called coronavirus disease 2019 (COVID-19), had caused more than 4.5 million cases and 310,000 deaths worldwide. ${ }^{1}$ Even though the virus mainly affects the lungs, ${ }^{2,3}$ recent studies have reported dermatological manifestations in patients with COVID-19. ${ }^{4,5}$ These findings could be related to a possible cutaneous tropism of the virus, however, the ability of SARS-CoV-2 to infect the skin is unknown.

The risk of a specific human organ or tissue for SARS-CoV-2 infection is determined by the presence of angiotensin 2-converting enzyme (ACE2) in its local cells, which is recognized by the spike protein (S) of the virus. ${ }^{6}$ Furthermore, protein $S$ activation by host transmembrane serine protease 2 (TMPRSS2) is crucial for this protein to carry out the fusion of viral and cell membranes. ${ }^{6}$ This way, SARS-CoV 2 tropism is determined by ACE2 and TMPRSS2 distribution in human tissues. Currently, there is little information on the expression of these viral entry factors in the skin. For this reason, a systematic analysis of public databases of human tissues gene expression was carried out in search for the presence of the ACE2 and TMPRSS2 genes in the skin.

\section{Method}

The absolute values of ACE2 and TMPRSS2 genes relative expression were retrieved from the GeneAtlas U133A, gcrma database included in the BioGPS portal (http://biogps.org). This database includes the mRNA expression pattern of 79 human tissues, for which Affymetrix U133 high-density oligonucleotide microarrays were used. Heat maps were constructed to represent the expression of the evaluated genes using relative expression values in terms of hybridization units for probes 222257_s_at in ACE2, and 211689_s_ at in TMPRSS2. T-cell hybridization units were used to establish a cutoff value above which the expression of both genes is considered detectable and higher than the background hybridization level.

RNA normalized expression value (NX) in ACE2 (ENSG00000130234) and TMPRSS2 (ENSG00 000184012) was also retrieved from the Human Protein Atlas database (HPA, http://www.proteinatlas.org), which includes transcriptomic data of three sequencing projects (HPA, GTEx and FANTOM5), generated by RNA sequencing (RNA-Seq) in 37 human tissues, 18 types of blood cells and 64 cell lines. ${ }^{7,8} \mathrm{NX}$ for each gene in each organ, tissue and cell line was defined as the highest value in all three data sources. The color gradients were constructed based on ACE2 and TMPRSS2 NXs, with cutoff established at one NX as the limit for the detection of genes in all tissues or cell types. ACE2 and TMPRSS2 levels in terms of protein expression in different tissues were collected from HPA. These data are obtained by immunohistochemistry and are presented with staining intensity, according to direct observation by an evaluator, according to the fraction of positive cells for each protein in each tissue (low, < $25 \%$; medium, 25 to $75 \%$; high > $75 \%$ ).

\section{Results}

Analysis of the ACE2 and TMPRSS2 genes tissue expression patterns in the BioGPS database showed a high ACE2 and TMPRSS2 co-expression in the small intestine and the kidney, but not in the skin (Fig. 1A).

To corroborate these findings, NX of the ACE2 and TMPRSS2 genes was obtained in the tissues registered at HPA. Since this database is based on RNAseq, its analysis can yield more specific and sensitive results. Data analysis confirmed ACE2 and TMPRSS2 co-expression in the small intestine and kidney, as well as in the duodenum, gallbladder and colon, but not in the skin (Fig. 1B). Since RNA expression general values of an organ may not reflect gene expression among local cell subsets, ACE2 and TMPRSS2 expression was also analyzed in the cell lines included in HPA, some of which originate in the skin. From this analysis, only the HaCaT cell-line of human immortalized keratinocytes was identified to express detectable levels of ACE2, as well as some cell lines originating in other tissues (Fig. 1C); however, no cutaneous-origin cell expressed TMPRSS2. HPA also includes information on the levels of tissue protein obtained by immunohistochemistry. According to these data, ACE2 and TMPRSS2 proteins tissue expression patterns were identified to be consistent with RNA expression data, which showed an absence of viral entry factors in different skin cell subtypes (Fig. 1D).

\section{Discussion}

The results of the analysis indicate that, at least under homeostatic conditions, healthy skin cannot be 

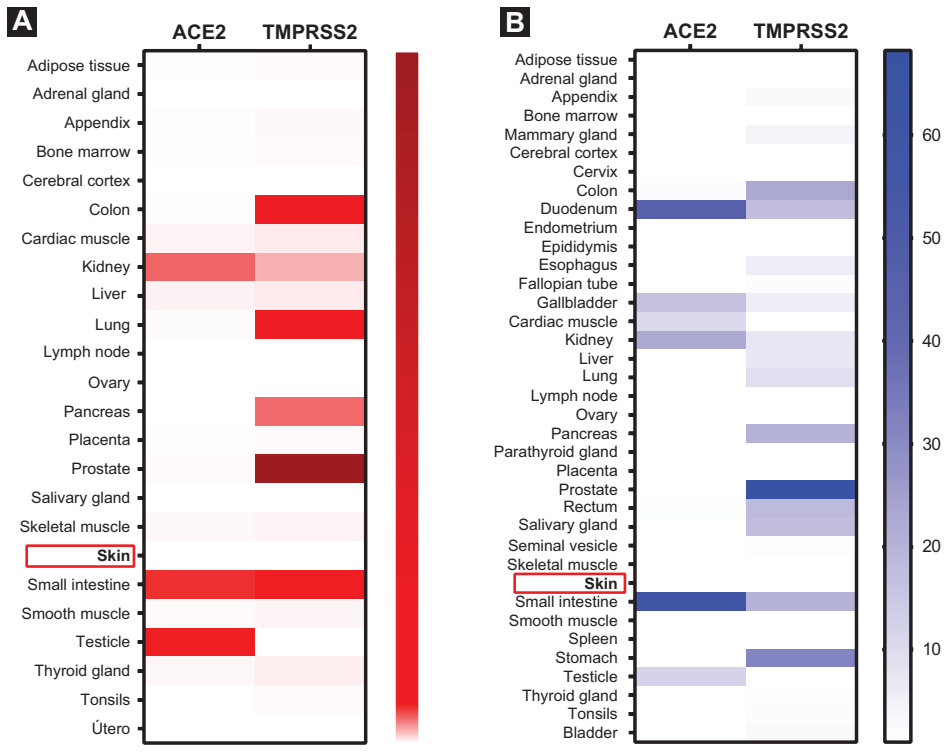

C
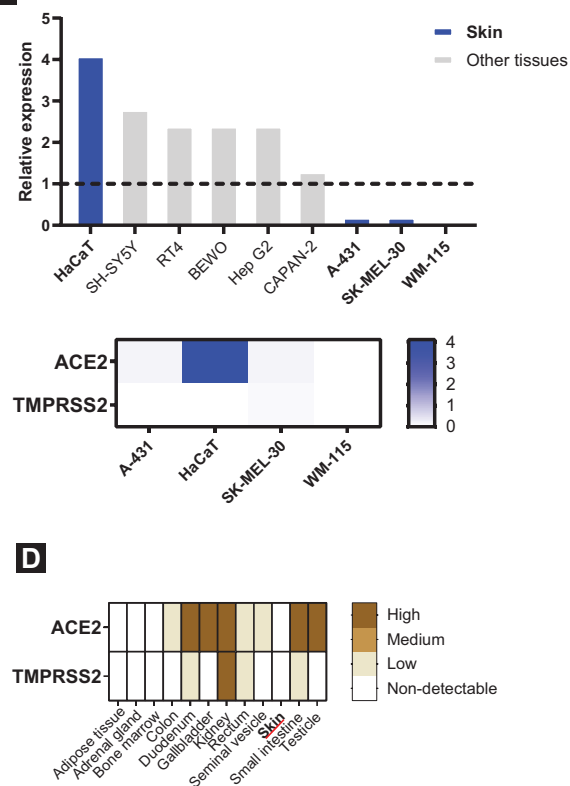

Figure 1. ACE2 and TMPRSS2 are not expressed in human skin. A) Patterns of ACE2 and TMPRSS2 tissue expression in the GeneAtlas U133A, gcrma database, available at BioGPS (http://biogps.org). The color gradient was constructed using relative expression values in terms of hybridization units for probes 222257_s_at in ACE2 and 211689_s_at in TMPRSS2. T-cell hybridization units were used to establish a cutoff value for detectable expression of both genes above the level of background hybridization. B) The normalized RNA expression values (NX) for the ACE2 (ENSG00000130234) and TMPRSS2 (ENSG00000184012) genes were retrieved from the Human Protein Atlas database (http:// www.proteinatlas.org). The NX for each gene in each organ or tissue represents the highest NX value in all three data sources. The heat color map gradient was constructed using ACE2 and TMPRSS2 NXs, with one NX cutoff as the limit for detection in all tissues or cell types. C) NX for ACE2 and TMPRSS2 in several human cell lines. Skin-origin cell lines NXs are shown in blue bars. D) ACE2 and TMPRSS2 protein levels in different tissues were retrieved from the HPA database. These data were obtained by immunohistochemistry and are presented with staining intensity, based on manual annotation according to the fraction of positive cells for each protein observed in each tissue (low, $<25 \%$; medium, 25 to $75 \%$; high, > 75\%).

directly infected by SARS-CoV-2; therefore, dermatological manifestations in patients with COVID-19 may have an indirect origin. Possible mechanisms of skin lesions during SARS-CoV-2 infection include the spread of the virus from adjacent tissues. In this sense, ACE2 expression has been found in the endothelium of several tissues, ${ }^{9}$ and recent evidence shows that SARS-CoV-2 can infect endothelial cells. ${ }^{10}$ Similarly, previous reports of ACE2 expression in the basal layers of epidermis and in hair follicles ${ }^{9,11}$ showed that this receptor can be detected mainly in cutaneous capillaries, but not in skin cells. Therefore, it is possible that SARS-CoV-2 affects the skin due to the contiguity of skin cells with local blood vessels endothelium.

Endothelial involvement might also result in endothelial dysfunction, microthrombosis, and hypoxia in different organs, including the skin. In fact, skin lesions in patients with SARS-CoV-2 infection, such as livedo reticularis, chilblains and necrosis of fingers and toes, are related to skin hypoxia. ${ }^{5}$ Endothelial infection and high circulating levels of inflammatory cytokines might also cause vasodilation and edema of the skin, which explains erythematous rash, urticaria and maculopapular rashes in some patients with COVID-19. ${ }^{4}$ Finally, a recent study shows that interferon gamma can increase ACE2 expression in lung epithelial cells. ${ }^{12}$ Therefore, it is possible that ACE2 and TMPRSS2 cutaneous expression can also be promoted by circulating inflammatory mediators produced in response to infection, thus increasing SARS-CoV-2 ability to infect the skin.

\section{Conclusions}

COVID-19 dermatological manifestations cannot be attributed to a direct effect mediated by the virus, since SARS-CoV-2 cannot infect healthy skin. However, future studies should assess the possibility that ACE2 expression on skin cells may be regulated by circulating inflammatory mediators produced in response to the virus, as well as in patients with 
chronic autoimmune and inflammatory dermatological conditions.

\section{Conflict of interests}

The authors declare that the investigation was carried out in the absence of any commercial or financial relationship that might be interpreted as a possible conflict of interests.

\section{Funding}

This research received no funding.

\section{Ethical disclosure}

Protection of people and animals The authors declare that no experiments were performed on humans or animals for this study.

Confidentiality of data The authors declare that they have followed the protocols of their work center on the publication of patient data.

Right to privacy and informed consent The authors declare that no patient data appear in this article.

\section{References}

1. World Health Organization [Internet]. Switzerland: Coronavirus disease (COVID-2019) situation reports. Situation report - 119; 2020.

2. Huang $C$, Wang $Y$, Li X, Ren L, Zhao J, Hu Y, et al. Clinical features of patients infected with 2019 novel coronavirus in Wuhan, China. Lancet. 2020;395:497-506.

3. Richardson S, Hirsch JS, Narasimhan M, Crawford JM, McGinn T, Davidson KW, et al. Presenting Characteristics, comorbidities, and outcomes among 5700 patients hospitalized with COVID-19 in the New York City area. JAMA 2020;323:2052-2059.

4. Recalcati S. Cutaneous manifestations in COVID-19: a first perspective. J Eur Acad Dermatol Venereol. 2020;34.

5. Galván-Casas C, Català A, Carretero-Hernández G, Rodríguez-Jiménez P, Fernández-Nieto D, Rodríguez-Villa Lario A, et al. Classification of the cutaneous manifestations of COVID-19: a rapid prospective nationwide consensus study in Spain with 375 cases. Br J Dermatol. 2020.

6. Hoffmann M, Kleine-Weber H, Schroeder S, Kruger N, Herrler T, Erichsen S, et al. SARS-CoV-2 cell entry depends on ACE2 and TMPRSS2 and is blocked by a clinically proven protease inhibitor. Cell. 2020;181:271-280.

7. Yu NY, Hallström BM, Fagerberg L, Ponten F, Kawaji H, Carninci P, et al. Complementing tissue characterization by integrating transcriptome profiling from the Human Protein Atlas and from the FANTOM5 consortium. Nucleic Acids Res. 2015:43:6787-6798.

8. Keen JC, Moore HM. The Genotype-Tissue Expression (GTEx) project: Linking clinical data with molecular analysis to advance personalized medicine. J Pers Med. 2015;5;22-29.

9. Hamming I, Timens W, Bulthuis ML, Lely AT, Navis G, van Goor H. Tissue distribution of ACE2 protein, the functional receptor for SARS coronavirus. A first step in understanding SARS pathogenesis. J Pathol. 2004;203:631-637.

10. Varga Z, Flammer AJ, Steiger P, Haberecker M, Andermatt R, Zinkernagel AS, et al. Endothelial cell infection and endothelititis in COVID-19. Lancet. 2020;395:1417-1418.

11. Grzegrzolka J, Swiatko K, Pula B, Zamirska A, Olbromski M, Bieniek A, et al. ACE and ACE2 expression in normal and malignant skin lesions. Folia Histochem Cytobiol. 2013;51;232-238.

12. Ziegler CGK, Allon SJ, Nyquist SK, Mbano IM, Miao VN, Tzouanas CN, et al. SARS-CoV-2 receptor ACE2 is an interferon-stimulated gene in human airway epithelial cells and is detected in specific cell subsets across tissues. Cell. 2020;181:1016-1035. 